\title{
Danmark og de fremmede, især de muslimske
}

\section{Vibeke Sperling}

\section{Flot artikelsamling om Danmarks problemfyldte møde med den arabisk-muslimske verden, tilegnet en særlig værdifuld stemme i debatten, Mehdi Mozzafari}

Tonny Brems Knudsen, Jørgen Dige Pedersen og Georg Sørensen (red): Danmark og de fremmede. Om mødet med den arabisk-muslimske verden. Academica 2009, 247 s.

Dette er en antologi, som fortjener stor udbredelse, da den tager fat om alle aspekter af et af Danmarks allerstørste problemer, at dets møde med 'de fremmede' er så problematisk.

Bogen er dedikeret en tidligere fremmed, som har kvalificeret debatten: Mehdi Mozaffari, professor i Islamiske Studier ved Institut for Statskundskab, Aarhus Universitet.

I forordet kaldes bogen "en hyldest til hans farverige og engagerede person samt til den dagsorden for forskning og debat, som han har været med til at sætte $\mathrm{i}$ gang på en lang række områder inklusive, reli- gion, radikalisering, terrorisme, civilisationernes sammenstød og mellemøstlig politik".

Ja i sandhed en bredt favnende forsker og debattør, den iransk fødte Mozaffari.

Og Mozaffari har en stor del af æren for, at vi nu har så stor ekspertise om Danmark og den arabiskmuslimske verden samlet på Aarhus Universitet, som bogen afspejler. De tretten forfattere kommer med få undtagelser fra det århusianske Institut for Statskundskab. Og undtagelsen Erling Bjøl var professor i international politik samme sted 196383. Det var Bjøl, som hentede Mozaffari til instituttet i 1981, netop "med det formål at bidrage til et bedre kendskab til verden uden for Europa".

Og denne "perser blandt vikinger', som Folkeuniversitetet i Århus 


\section{LITTERATUR}

har introduceret Mehdi Mozaffari, har siden kvalificeret den danske debat og forskning i næsten uvurderlig høj grad.

Bogens elleve bidrag behandler tre hovedemner: 1) fremmedfrygt, integration og dansk politik, 2) religion, radikalisering og de-radikalisering, 3) Danmarks og den vestlige verdens møde med den arabisk-muslimske verden i international politik.

Christoffer Green-Pedersen skriver om, hvordan flygtninge- og indvandrerspørgsmålet kom så høj op på den politiske dagsorden. Den afgørende faktor var "den borgerlige oppositions fokus på emnet fra 1993 og frem".

Det tvang Socialdemokratiet til at forholde sig til emnet, "som siden er blevet en central bestanddel af dansk partipolitik til glæde for ikke mindst Dansk Folkeparti”.

Bidraget maner til eftertanke, om det socialdemokratiske medløberi var nødvendigt i en situationen, hvor en indvandrerkritisk befolkning og et øget antal flygtninge og indvandrere nok var forudsætninger for udviklingen, "men er ikke i sig selv tilstrækkelige forklaringer". Politiseringen var afgørende.

"Denne politisering er en af de væsentligste udviklinger i nyere dansk politisk historie. Den er for eksempel en af nøglerne til at forstå regeringsskiftet i 2001".

Forfatteren ser også denne politisering som af "helt afgørende betydning for Danmarks forhold til om- verdenen" og han kan ikke forestille sig, at debatten om Jyllands-Postens Muhammedtegninger ville være blevet den samme "uden den forudgående politisering af flygtninge- $o g$ indvandrerspørgsmålet”.

\section{Større accept i Sverige}

Jens Peter Frølund Thomsen drager sammenlignende studier med blandt andet Sverige, hvor flygtninge- og indvandrerspørgsmålet aldrig er blevet samme partipolitiske stridspunkt som i Danmark, og der findes ikke i Sverige "et sidestykke til Dansk Folkeparti med repræsentation i parlamentet".

Men det allervigtigste er nok, at partierne i Sverige "tilsyneladende er ret enige om at acceptere det flerkulturelle samfund, hvilket ikke er tilfældet i Danmark".

Erfaringerne peger på, at det er nye højrefløjspartier, som slipper ånden ud af flasken, og venstrefløjen så står i en helt ny situation og kommer halsende bagefter. Debatten "kan ikke puttes tilbage i flasken" og den politiske balance rykker til højre.

Manni Crone skriver om, hvad det er for folk, som vi har med at gøre i terrorsager, herunder Vollsmose-sagen, Glostrup-sagen, sagen mod boghandleren fra Brønshøj, Said Mansour, og den såkaldte Glasværksvej-sag.

Vi har et vist kendskab til de ekstremistiske islamister, men det er 
slet ikke dem, som vi står overfor ifølge Crone. "Deres opfattelse af islam og deres religiøse referencer er på ingen måde islamistiske, men har langt større affinitet med 'salafismen', som er en ny ideologi med ideologiske rødder i Saudi-Arabien".

Når unge drages til terror, skyldes det ikke islamisme men snarere islamismens krise, at islamismen simpelthen er blevet for tam for de radikale.

Islamisterne har ønsket at skabe islamiske stater, baseret på social retfærdighed, islamisk økonomi og adskillelse af kvinder og mænd i det offentlige rum. For Salafi-jihadismen spiller dommedag derimod en central rolle. "Det primære er ikke længere at skabe et godt samfund i denne verden, men - da dommedag er nær - at sikre sig adgang til den næste".

Dommedagsforestillingens grundlag er global kamp mellem muslimer og Vesten.

Efter få år med 'hjemmedyrket' terrorisme, som primært truede europæiske samfund, mener Manni Crone, at vi vil se en ny trend, hvor unge jihadister drager ud for at kæmpe uden for Europa, bl.a. i Afghanistan, Somalia og Yemen.

Det er herligt at læse andre forudsigelser, end at den 'hjemmedyrkede' terrorisme bare bliver værre i europæiske samfund. Men det lover selvfølgelig ikke godt for den internationale indsats i de pågældende lande.

\section{Luthers tilbagevenden}

Svend Andersen skriver om Martin Luthers tilbagevenden, da "indvandringen og islams tilstedeværelse $\mathrm{i}$ landet har aktualiseret grundlovens tale om, at den evangelisk-lutherske kirke er den danske folkekirke".

Den lutherske tradition er blevet en væsentlig del af den såkaldte værdikamp. Et udtryk herfor er jo, at Luther er kommet med i demokratikanonen.

"Mit spørgsmål er, om billedet af en luthersk kristendom som garant for demokrati og sekularisering og som bolværk mod radikalisering er korrekt. Mit svar vil være, at billedet er stærkt forenklet".

Andersen påpeger, at radikalisme har haft mange udtryk, også i den lutherske tradition. Martin Luther var jo ikke just en demokratisk herre. Han så fornyelse som befrielse fra ydre autoriteter og magter, "men - og det er det afgørende - kun autoriteter og magter, der har at gøre med menneskers forhold til Gud". Befrielsen kunne ifølge Luther ikke overføres til det sociale og politiske område. "Her må ifølge Luther stadigvæk herske autoritære over-/underordningsforhold".

Den lutherske kristendomsforståelse indebar for bl.a. Thomas Münzer, at det var fulgt legitimt at dræbe fjender af vor Gud, præcis som islamister ser det som legitimt at dræbe 'ikke troende'.

Men Andersen mener, at vi på 


\section{LITTERATUR}

baggrund af vores egen kulturelle baggrund ikke kan udelukke, at islam udvikles på samme måde, "således at radikalismen i islamistiske udgave bliver den store undtagelse".

Og i dag er der jo kun få ekstremistiske kristne grupper, som finder det legitimt at dræbe for Gud.

Debatten om adskillelse af kirke og stat har raset, men et godt modargument er, at en sådan adskillelse vil give frit spil for alskens mærkværdige kristne sekter som i USA.

\section{Religionslighed?}

Svend Andersen spørger med rette, om kristendommen stadig skal præge det politiske. Og om det overhovedet giver mening at tale om en kristen stat. "Eller skal den evangelisk-lutherske kirke give afkald på sin privilegerede stilling, så vi ikke kun har religionsfrihed, men også religionslighed".

Ja, oplagt fra et demokratiske perspektiv, men der er formentlig langt igen i et samfund, der benægter sin egen multikulturelle identitet.

Ifølge Tina Magaards bidrag er multikulturalisme og sekularisme to forskellige udgangspunkter i debatten om terrorbekæmpelse i Europa.

"I Danmark har man i nogen grad valgt at støtte sig til Storbritannien", der "repræsenterer det, man kalder multikulturalisme, i modsætning til et land som Frankrig, som siden 1905 har defineret sig som sekulært".
Den franske stats sekularisme, laicité, betyder, at dens embedsmænd skal være neutrale, og at religion nedtones i det offentlige rum. Vi kender jo alle konflikterne også $\mathrm{i}$ Frankrig, men det forbløffende er, at undersøgelser viser, "at Frankrig er det land i den vestlige verden, hvor flest muslimer føler sig som del af det nationale fællesskab og definerer sig selv først som franskmænd, dernæst som muslimer".

Den røde tråd igennem sammenligningen imellem Frankrig og Storbritannien er 'kollektive versus individuelle rettigheder', når det gælder det terrorforebyggende arbejde. Men når danske myndigheder har hældet mere til erfaringerne i Storbritannien, må man spørge, hvor langt det overhovedet rækker at overføre erfaringer fra et land, hvor samfundets multikulturelle karakter er fuldt ud erkendt, til et land som Danmark, hvor det ikke er tilfældet.

Lasse Lindekilde ser på tilfælde, hvor forsøg på at sætte ind imod radikalisering af de unge er ført til det modsatte. Her bliver vi ført ned på gadeplan og en interview-unders $\varnothing$ gelse i Aarhus af, hvordan de undersøgte selv opfatter officielle de-radikaliseringstiltag. Opfattelsen er udbredt, at 'de-radikaliseringstiltag virker imod hensigten'. Det skyldes dog ikke bare tiltagene i sig selv. De skeptiske over for tiltagene havde også "generelt negative opfattelser af den politiske vilje blandt ikkemuslimer vis-a-vis muslimer”. Også 
her handler det om mangel på dia$\log$ og derfor dårlig kommunikation.

Nikolaj Petersen beskæftiger sig med globalisering og udenrigspolitik og dykker ned i danske strategier under Muhammedkrisen 2005-08.

"Politisk-kulturel globalisering har haft vanskeligere vilkår end andre aspekter af globaliseringen, idet nationalisme og religion, især islam, har vist sig som en formidabel modspiller for den vestlige sekulære liberalisme, der bærer globaliseringen", skriver Nikolaj Petersen i sit bidrag, der blandt andet tager fat om dette generelt alt for underprioriterede aspekt i globaliseringsdebatten.

\section{Globaliseringen tog magten}

Men Muhammedkrisen 2005-08 oplevede Danmark et internationalt stormvejr, "som med al ønskelig tydelighed understregede, at indenrigs- og udenrigspolitik ikke længere lader sig isolere fra hinanden". At man ikke i en globaliseret verden kan forvente, at nogle tegninger $\mathrm{i}$ en dansk avis forblev et fænomen, der kun ragede danskere, kom bag på landet og dets regering. Eller, som Nikolaj Petersen udtrykker det, "globaliseringen tog så at sige magten fra den danske regering”. Her er han på tværs af alle fejltrin fra regeringen side inde ved kernen af problemet: en regering, som ikke anede, hvad der havde ramt den.

Thomas Olesens bidrag viser, at der "næppe findes noget mere ef- fektivt middel til at udbrede sit budskab transnationalt end terrorisme".

Nyhedskanaler som al-Jazeera og al-Arabiya vil generelt være mere åbne for at viderebringe budskabet end CNN og BBC World. Men ved siden af de traditionelle medier gør terrorister stadig mere brug af internet, som "har gjort det muligt for aktivister af alle slags at kommunikere direkte med et stort transnationalt publikum uden først at skulle bevæge sig igennem de traditionelle mediers nyhedsfilter".

Medierne har ifølge Olesen et væsentligt ansvar for ikke at bidrage til at, "stimulere den frygtskabelse, der i sidste ende kun bidrager til terroristernes mål”. Her mangler svar på, hvordan medierne kan undgå det, hvis de samtidig skal holde borgerne informeret om terrorhandlinger.

Morten Valbjørn analyserer konsekvenserne af, at islam i dag både er magtens og oppositionens sprog i Mellemøstens politik, der "som oftest - men ikke altid - har været præget af en tæt sammenvævning af religion og politik".

Men det betyder ikke, at der er islamiske standardsvar. "Det afspejler sig i manglen på konsensus om, hvad det islamiske svar på givent spørgsmål måtte være".

Vi bør sætte os meget bedre ind i den muslimske-arabiske kultur. Det har fået rigtig mange danskere til at læse Koranen, som ifølge Valbjørn imidlertid langtfra fungerer som det mest oplagte introduktionsværk. 


\section{LITTERATUR}

Bogens afslutning, Erling Bjøls 'Fra og om muslimernes verden', fungerer næsten som en mini-introduktion med artikler fra den arabiske-muslimske verden siden Anden Verdenskrig. I den seneste artikel fra maj 2006 sætter Bjøl kniven i Danmarks tabte uskyld: "Forleden fortalte en spindoktor i BBC's europæiske program om en undersøgelse af Danmarks image ude i verden. Det var ikke rart at høre på i en udsendelse, der aflyttes over hele Europa. Vi var selvtilfredse og selvoptagne for ikke at sige fremmedfjendske. Danmark skulle ifølge BBC være det eneste land, hvis 'nationale brand' er blevet 'markant svækket'".

Det er, som de tre redaktører skriver indledningsvis, bogens hensigt at bidrage til den offentlige og poli- tiske debat om disse emner herhjemme. Det er generelt let tilgængelige bidrag til debatten. De kunne være endnu mere bredt tilgængelige med en oversættelse af akademisk redskabsgymnastik som 'diskursiv mulighedsstruktur'.

Det er en bolsjebutik af dybtgående undersøgelser af de enkelte emner. Redaktørerne skriver, at bidragene "næsten uundgåeligt vil få læseren til at genoverveje forholdet mellem Danmark og de fremmede én gang til". Det er næsten for beskedent, for det gør bogen helt uundgåeligt. Bare flot.

Vibeke Sperling er Østeuropakorrespondent på dagbladet Politiken og redaktør af Udenrigs. 